\title{
Fulminant Mycoplasma Pneumoniae Pneumonia with Marked Elevation of Serum Soluble Interleukin-2 Receptor
}

\author{
Shigeji Ito, Yoshimichi Abe, Keiko Kinomoto, Takaya SaItoh, Takuji Kato, \\ Yoshihiro KoHLI, Masaru KuRIYAMA, Tetsuo SAKAI* and Takeshi IshIZAKI*
}

\begin{abstract}
We treated a married couple who developed Mycoplasma pneumonia at the same time, and whose clinical courses and serum soluble interleukin-2 receptor (sIL-2R) levels were markedly different. The 30-year-old wife developed acute respiratory failure and her sIL-2R levels were extremely increased. After pulse therapy, her clinical state was improved, with a marked decrease in sIL-2R. In contrast, the 36-year-old husband, also suffered from the pneumonia with a moderate increase of sIL-2R, and recovered without any complications. The difference in their clinical states may be reflected in their serum sIL-2R levels, a marker of $\mathrm{T}$ cell activation in vivo.

(Internal Medicine 34: 430-435, 1995)
\end{abstract}

Key words: acute respiratory failure, interstitial pneumonia, pulse therapy

\section{Introduction}

Although Mycoplasma pneumoniae pneumonia is usually a self-limited disease, some cases are known to develop a severe pneumonia with acute respiratory failure $(1,2)$. In addition, other general complications due to Mycoplasma pneumoniae, such as Guillain-Barré syndrome, have been reported (3). Therefore, current evidence suggests that this bacteria induces various diseases, which may be attributable to the bacterial virulency or the host's immune responses against this bacteria (4).

Recently, we treated a married couple who developed $\mathrm{Myco}$ plasma pneumoniae pneumonia at the same time, and whose clinical courses were markedly different. In addition, differing levels of the serum soluble interleukin-2 receptor (sIL-2R), recently found to be a marker of $\mathrm{T}$ cell activation (5), were observed. Here, we present these cases and discuss the pathogenesis of Mycoplasma pneumoniae from the viewpoint of immunological responses.

\section{Case Report}

\section{Case 1: the wife (30-year-old female)}

On Dec. 21,1993 , she developed a high fever $\left(40^{\circ} \mathrm{C}\right)$ without any known reason, and was treated with NSAIDs by her family physician. The next day, she complained of a cough and sputum. Although she took the medicine given by the doctor, her clinical symptoms did not improve, thus, she visited to our hospital on Dec. 24, and was hospitalized on that day (Fig. 1). She had no history of other severe diseases or hypersensitivity to any drugs. On physical examination, though she had no anemia or jaundice, her face looked pale. Mild erythema was observed on her face and anterior neck. No superficial lymph node swelling was observed. No rales or abnormal heart murmur was heard, despite moderate cough and serous sputum. Hepato-splenomegaly was not observed. However, chest X-ray revealed lobar pneumonia in the right lower lobe (Fig. 2). In that lobe, there was mild volume loss; air bronchogram from the main bronchus to the peripheral respiratory bronchioles exhibited non-obstructive atelectasis. In addition, multiple patchy shadows in the right upper and left lingula lobe were also observed on tomography (Fig. 3). In the laboratory data, leukocytopenia with marked nuclear left shift without eosinophilia was observed (Table 1). These findings suggested that severe inflammation was present in this patient. Mild liver dysfunction was noted. On the serological tests, cold agglutinin test was normal and anti-Mycoplasma pneumoniae antibody was negative on admission. Later on Jan. 4, 1994, these two markers of Mycoplasma pneumoniae became positive. AntiLegionella pneumophila antibody, anti-HTLV-I antibody and anti-C. psittaci antibody were negative; other viral antibodies were not examined. On microbiological analysis of her sputum, no significant bacteria was detected. The purified protein derivative (PPD) reaction was negative, although she had been

From the Second Department of Internal Medicine, Fukui Medical School and *the Third Department of Internal Medicine, Fukui Medical School, Fukui Received for publication August 8, 1994; Accepted for publication December 26, 1994

Reprint requests should be addressed to Dr. Shigeji Ito, the Second Department of Internal Medicine, Fukui Medical School, 23-3, Shimoaizuki, Matsuoka-cho, Yoshida-gun, Fukui 910-11 


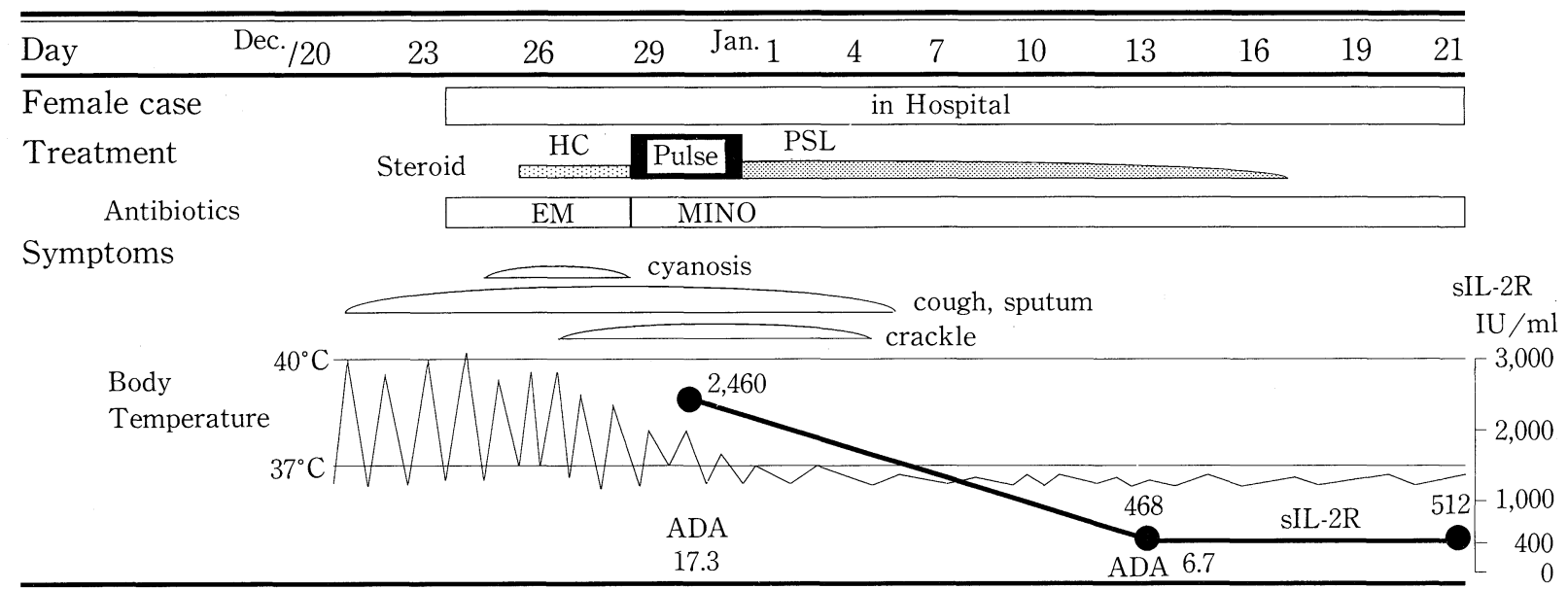

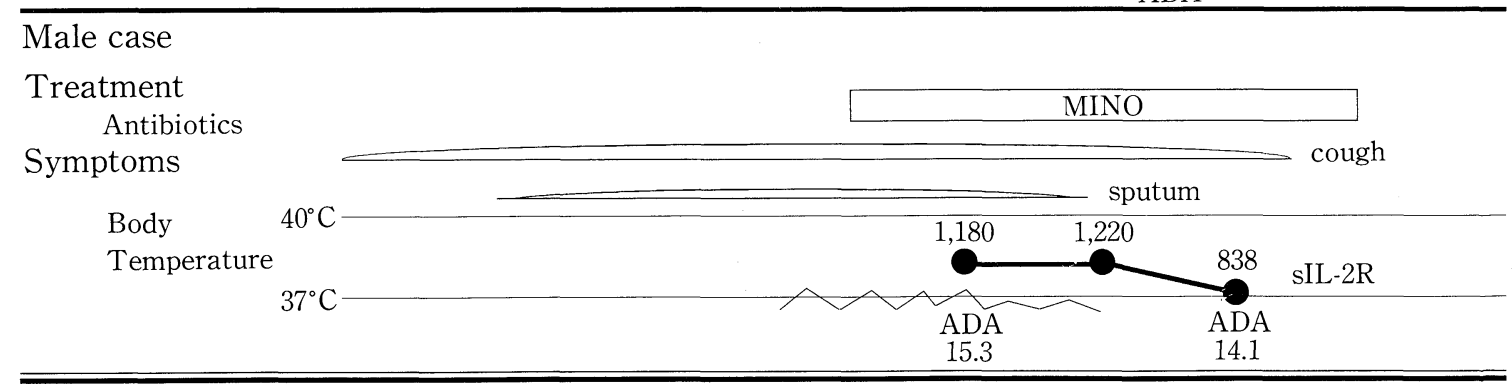

Fig. 1. Clinical course of two cases, plus serum soluble interleukin 2 receptor (sIL-2R) levels and adenosine deaminase (ADA) activities. Top: 30-year-old female, Bottom: 36 -year-old male, HC, $300 \mathrm{mg} /$ day hydrocortisone, Pulse: 1,000 mg/day methylprednisolone, PSL: prednisolone from $30 \mathrm{mg} /$ day to $5 \mathrm{mg} /$ day, EM: $1,000 \mathrm{mg} /$ day erythromycin, MINO: $200 \mathrm{mg} /$ day minocyclin. ADA activities were expressed as IU/L (normal range: 9-19). SIL-2R levels were expressed as IU/ml (normal range: 0-400).

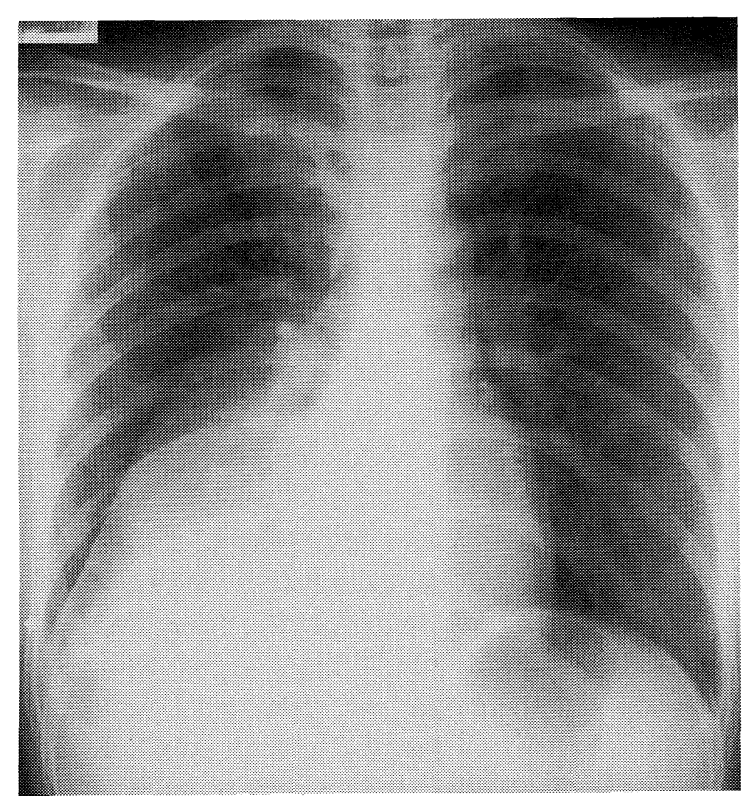

Fig. 2. PA view of chest $\mathrm{X}$-ray film on admission (female case).

received BCG inoculation when in junior high school.

From these clinical symptoms, signs, chest X-ray and laboratory data, we thought her pneumonia to be a non-bacterial

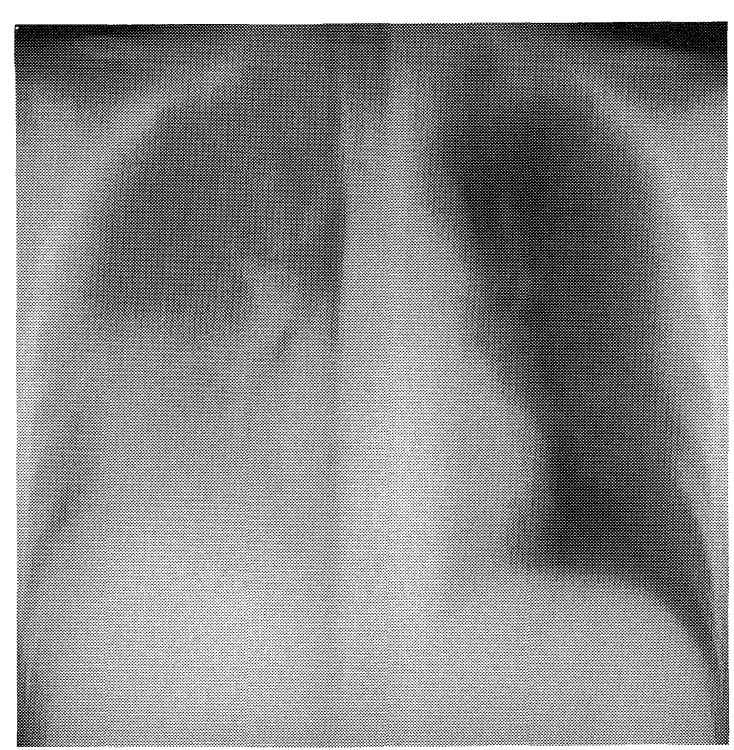

Fig. 3. Tomography of chest X-ray film, $8 \mathrm{~cm}$ from her back on admission.

pneumonia, such as Mycoplasma pneumoniae pneumonia. For treatment, $1000 \mathrm{mg} /$ day erythromycin was administered intravenously. However, the following day, her symptoms wors- 
Table 1. Laboratory Data (Examination date, month/day)

\begin{tabular}{|c|c|c|c|c|c|c|c|}
\hline \multicolumn{5}{|c|}{ Female Case } & \multicolumn{3}{|c|}{ Male Case } \\
\hline Hematology & $(12 / 24)$ & Serology & \multicolumn{2}{|c|}{$\underline{\text { Bronchoalveolar lavage }}$} & Hematology & $(1 / 4)$ & Serology \\
\hline White blood cells & $2,800 / \mu \mathrm{l}$ & Rheumatoid factor & fluid (BALF) & $(12 / 28)$ & $\overline{\text { White blood cells }}$ & $7,400 / \mu 1$ & 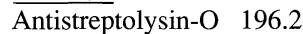 \\
\hline Red blood cells 4 & $455 \times 10^{4} / \mu \mathrm{l}$ & Antistreptolysin-O & Total cells & $2.2 \times 10^{6} / \mathrm{ml}$ & Red blood cells & $503 \times 10^{4} / \mu 1$ & $\mathrm{IgG} \quad 1,386 \mathrm{mg} / \mathrm{dl}$ \\
\hline Hemoglobin & $13.7 \mathrm{~g} / \mathrm{dl}$ & Anti-DNA antibody & Macrophage & $67 \%$ & Hemoglobin & $13.9 \mathrm{~g} / \mathrm{dl}$ & $443 \mathrm{mg} / \mathrm{dl}$ \\
\hline Hematocrit & $39.4 \%$ & Lupus erythematosus test (-) & Lymphocyte & $30 \%$ & Hematocrit & $42.6 \%$ & $293 \mathrm{mg} / \mathrm{dl}$ \\
\hline Platelet & $11.8 \times 10^{4} / \mu 1$ & $\mathrm{IgG} \quad 1115 \mathrm{mg} / \mathrm{dl}$ & Neutrophil & $3 \%$ & Platelet & $65.1 \times 10^{4} / \mu 1$ & $261 \mathrm{U} / \mathrm{ml}$ \\
\hline Hemogram & $(\%)$ & $126 \mathrm{mg} / \mathrm{dl}$ & Eosinophil & $0 \%$ & Hemogram & $(\%)$ & \\
\hline Band neutrophil & 83 & $114 \mathrm{mg} / \mathrm{dl}$ & & & Band neutrophil & 3 & \\
\hline Segmented neutrop & phil & $54.5 \mathrm{U} / \mathrm{ml}$ & Blood gas ana & lysis $(12 / 26)$ & Segmented neutr & trophil & Mycoplasma $(\mathrm{CF})$ \\
\hline Eosinophil & 0 & Anti-L.pneumophila antibody & Room air & & Eosinophil & 1 & $640 \times(1 / 4)$ \\
\hline Lymphocyte & 12 & $(-)(1 / 13)$ & $\mathrm{pH}$ & 7.426 & Basophil & 0 & $\rightarrow 1280 \times(1 / 11)$ \\
\hline Monocyte & 2 & Anti- $H T L V-I$ antibody & $\mathrm{PaO}_{2}$ & 37.8 torr & Lymphocyte & 28 & Cold Agglutinin test \\
\hline C-reactive protein 3 & $33.7 \mathrm{mg} / \mathrm{dl}$ & $(-)(12 / 28)$ & $\mathrm{PaCO}_{2}$ & 35.6 torr & Monocyte & 5 & $1025 \times(1 / 4)$ \\
\hline Erythrocyte sediment & ntation rate & Anti-C. psittaci antibody & Base Excess & 0.2 & Fibrinogen & $478.4 \mathrm{mg} / \mathrm{dl}$ & \\
\hline & $45 / \mathrm{h}$ & $(-)(12 / 28)$ & $\mathrm{A}-\mathrm{aDO}_{2}$ & 67.15 & C-reactive protein & $1.48 \mathrm{mg} / \mathrm{dl}$ & \\
\hline Chemistry & $(12 / 24)$ & & & & & & \\
\hline$\overline{\operatorname{AST}(10-40)}$ & $42 \mathrm{IU} / 1$ & $\underline{\text { Sputum culture }}$ & & & Chemistry & $(1 / 4)$ & \\
\hline $\operatorname{ALT}(5-40)$ & $35 \mathrm{IU} / 1$ & Tuberculosis & & & $\operatorname{AST}(10-40)$ & $25 \mathrm{IU} / 1$ & \\
\hline $\mathrm{LDH}(-440)$ & $474 \mathrm{IU} / 1$ & $\alpha$-Streptococcus & & & $\operatorname{ALT}(5-40)$ & $30 \mathrm{IU} / 1$ & \\
\hline $\operatorname{ALP}(-260)$ & $151 \mathrm{IU} / 1$ & Purified protein derivative & & & LDH $(-440)$ & $477 \mathrm{IU} / 1$ & \\
\hline $\operatorname{rGTP}(-50)$ & $51 \mathrm{IU} / 1$ & $(-)(12 / 26)$ & & & $\operatorname{ALP}(-260)$ & $201 \mathrm{IU} / 1$ & \\
\hline Total Protein & $6.4 \mathrm{~g} / \mathrm{dl}$ & & & & rGTP $(-50)$ & $50 \mathrm{IU} / 1$ & \\
\hline Albumin & $3.7 \mathrm{~g} / \mathrm{dl}$ & & & & $\operatorname{LAP}(-170)$ & $50 \mathrm{IU} / 1$ & \\
\hline r-globulin & $15.6 \%$ & Mycoplasma $(\mathrm{CF})$ & & & Total protein & $7.0 \mathrm{~g} / \mathrm{dl}$ & \\
\hline ZTT & $4.5 \mathrm{U}$ & $(-)(12 / 24) \rightarrow 320 \times(1 / 4)$ & & & Albumin & $3.6 \mathrm{~g} / \mathrm{dl}$ & \\
\hline TTT & $1.3 \mathrm{U}$ & Cold Agglutinin test & & & Total bilirubin & $0.3 \mathrm{mg} / \mathrm{dl}$ & \\
\hline Total bilirubin & $1.0 \mathrm{mg} / \mathrm{dl}$ & $8 \times(12 / 24) \rightarrow 128 \times(1 / 4)$ & & & Blood urea nitroge & en $7 \mathrm{mg} / \mathrm{dl}$ & \\
\hline Blood urea nitrogen & $8.0 \mathrm{mg} / \mathrm{dl}$ & & & & Creatinine & $0.8 \mathrm{mg} / \mathrm{dl}$ & \\
\hline Creatinine & $0.8 \mathrm{mg} / \mathrm{dl}$ & & & & & & \\
\hline
\end{tabular}

CF: complement fixation method, $\mathrm{A}-\mathrm{aDO}_{2}$ : Alveolar arterial $\mathrm{O}_{2}$ pressure difference.

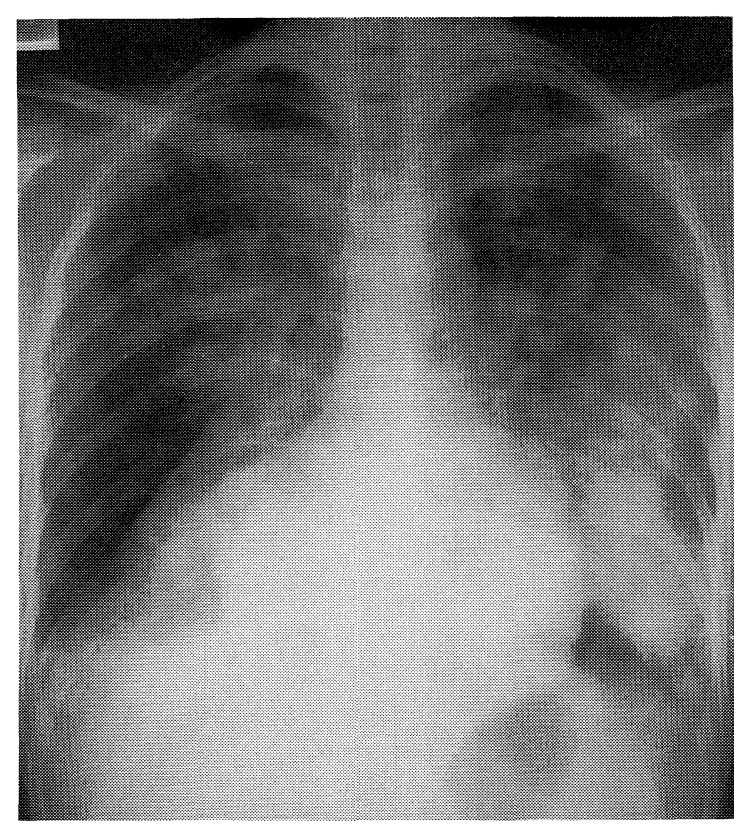

Fig. 4. Chest X-ray film 2 days after admission. Severe interstitial shadow in addition to the right lower lobar pneumonic shadow was observed in both lungs (female case). ened and cyanosis developed (Fig. 1). Arterial blood gas analysis revealed severe acute respiratory failure, with patchy interstitial shadows distributed widely in both lungs on the chest X-ray, appearing like adult respiratory distress syndrome (Fig. 4). With the administration of oxygen and hydrocortisone, her general condition was slightly improved. To obtain the true diagnosis, bronchoalveolar lavage fluid (BALF) collection and transbronchial lung biopsy (TBLB) were performed. On BALF findings, macrophages were decreased and lymphocytes were increased, suggesting not a bacterial pneumonia but an interstitial pneumonia of unknown origin (Table 1). The TBLB also showed intact alveolar spaces and moderate interstitial inflammation with mild fibrin deposition (Fig. 5). Therefore, pulse therapy of $1000 \mathrm{mg} /$ day methylprednisolone for 3 days was administered, followed with $30 \mathrm{mg} /$ day prednisolone, per os. As a result, her symptoms and signs were remarkably improved. The chest $\mathrm{X}$-ray was also improved and the lung fields became clear (Fig. 6 ). She became healthy and was discharged on Jan. 21 without any sequelae.

\section{Case 2: the husband (36-year-old male)}

The husband complained of a mild cough from about Dec. 20,1993 , but because his wife was in the hospital and his symptom was not so severe, he first came to our hospital on Jan. 3, 1994 (Fig. 1). He had a dry cough and minimal fever. There 


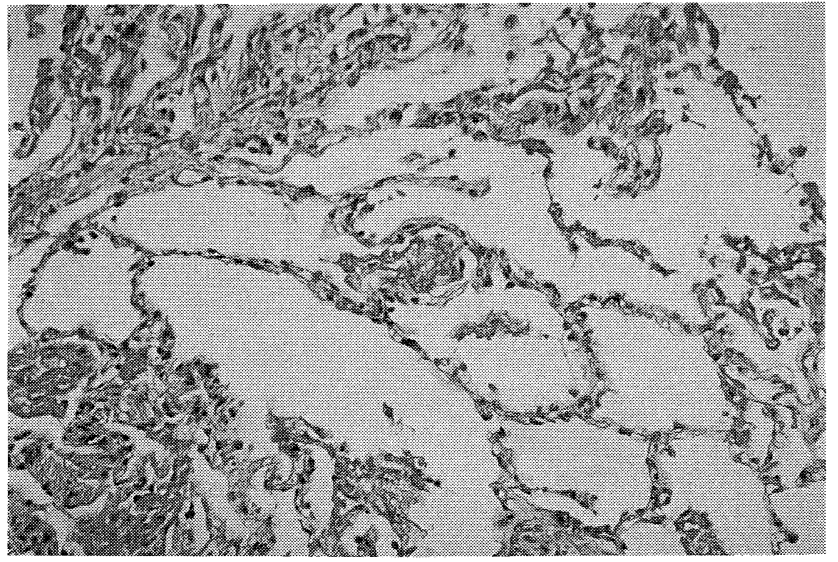

Fig. 5. Transbronchial lung biopsy (TBLB) finding showed mild fibrin deposition and interstitial inflammation with intact alveolar spaces.

were no rales or wheeze. However, the chest X-ray revealed a fine glass-like shadow on the left lower lung field (Fig. 7). The next day, blood analysis revealed a high cold agglutinin test and anti-Mycoplasma pneumoniae antibody titer (Table 1). He was treated as an outpatient with $200 \mathrm{mg}$ /day minocyclin per os and recovered in 2 weeks without any respiratory failure or complications.

In these two patients, the clinical symptoms were markedly different. To evaluate the immunological state of these patients, we measured serum sIL-2R levels and adenosine deaminase (ADA) activities (Fig. 1). As a result, marked elevation of sIL$2 \mathrm{R}$ was observed in the wife during the period of acute respiratory failure. After pulse therapy, the sIL-2R level was decreased to the normal level. On the other hand, sIL-2R levels of the husband were lower than those of the wife, though their levels remained higher than the normal level during the disease period. Unfortunately, the sIL-2R level of the husband after

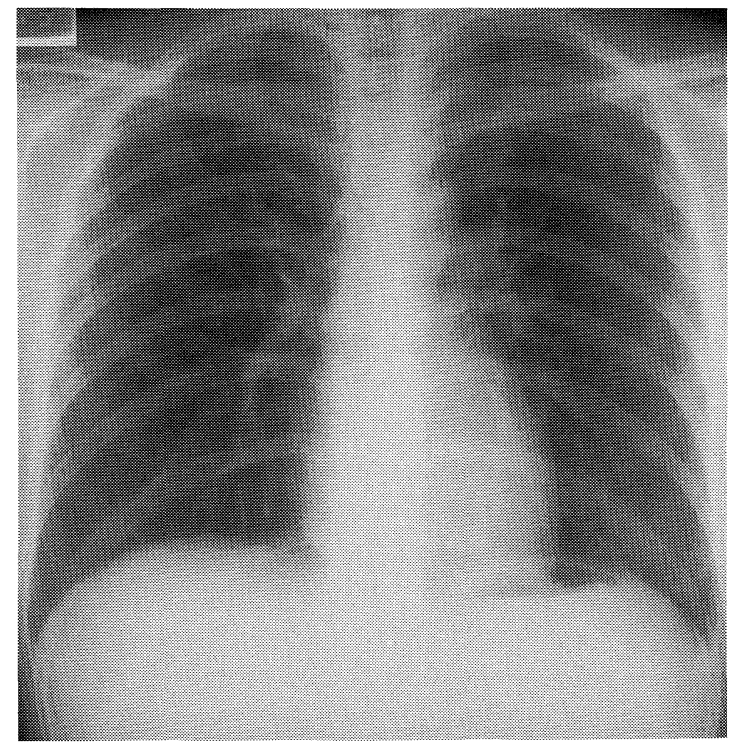

Fig. 6. Chest $\mathrm{x}$-ray film when she recovered after pulse therapy, on Jan. 11, 1994.

recovery could not be examined. ADA activities in this couple were within the normal range, and no difference was observed between the two.

\section{Discussion}

Recently, Mycoplasma pneumoniae infection is known to lead to various diseases. In some cases, it causes severe and fatal pneumonia, called fulminant pneumonia $(1,6)$. In general, these varieties depend on both the bacterial strains and the host's responses (4). According to previous reports, more virulent strains, which can produce peroxide, cause severe

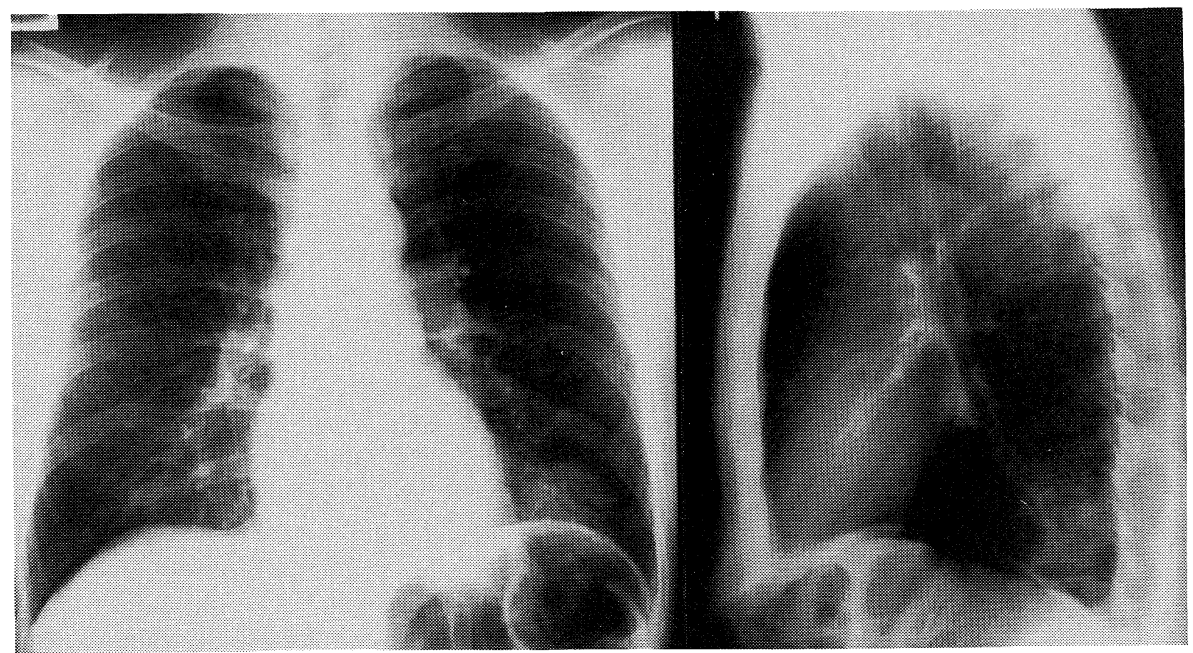

Fig. 7. Chest x-ray films of male patient on Jan. 3, 1994. 
disease $(4,7)$. The ability to attach to ciliated epithelium in the respiratory system is also one of the virulent factors $(4,8)$. However, in this couple, the onset was almost the same, and so, the strains of the patients might be the same or very similar. Nevertheless, the symptoms and clinical courses were markedly different. Although the wife had the possibility to develop other diseases in addition to Mycoplasma pneumonia, it is not so likely that a healthy person suffers from many infectious diseases at the same time. In addition, drug-induced interstitial pneumonia is also less likely, because she had no history of hypersensitivity to drugs and her laboratory data showed no leukocytosis, eosinophilia nor elevation of $\operatorname{IgE}(9,10)$. Chest Xray also showed lobar pneumonia, not a diffuse shadow at first, even though erythema was found. In consideration of these findings, the development of severe pneumonia in the wife might have been due to Mycoplasma itself, and the hosts' immune response against the bacteria might affect the clinical features, although other unknown factors might also affect the features.

Since the first report of fatal Mycoplasma pneumoniae infection (11), many cases of severe pneumonia with acute respiratory failure were reported. In only the past 10 years in Japan, more than 25 cases were reported according to Igaku Chuo Zasshi (Japona Centra Revuo Medicina) (2, 12-33). The age of more than half of the patient was only between 15 and 40 , and most of the patients had no complications or background diseases. However, immunological abnormalities were reported in most of these cases. This tendency was similar to the cases reported throughout the world, as discussed by Wakasa et al (2). In general, the immunity of these patients against various bacteria might be sufficient to protect them from various diseases. There are some reports that the symptoms were severe if the patients had been given a vaccine in their childhood (34). These data suggest that it is not the immunodeficiency, but rather the immunological hypersensitivity against Mycoplasma pneumoniae causes more severe pneumonia $(2,33)$. In addition, on the immunological analysis of BALF, the $\mathrm{CD}_{4}$ positive $\mathrm{T}$ cells, which bind to the HLA class II antigen positive cells, were found to be accumulated in the lung, and activated strongly to the bacterial antigens (35).

Therefore, we measured serum sIL-2R to evaluate the immunological state of the patients. Soluble IL-2R is a released extracellular domain of the alpha-chain of IL-2R. Based on many reports, the majority of serum sIL-2R is elaborated by activated T cells, and hence, the sIL-2R level can be used as a marker of T lymphocyte activation in vivo $(5,36,37)$. We found an elevated serum sIL-2R level in both of the present patients, but their levels were markedly different. According to previous reports (36-39), markedly elevated levels of sIL-2R have been observed in patients with hematologic malignancies, autoimmune disorders and pulmonary disorders such as asthma, sarcoidosis, interstitial pneumonia and active tuberculosis. Among them, interstitial pneumonia as a complication of interferon (IFN) therapy for chronic hepatitis is thought to be a result of severe T cell activation by IFN, as expressed by the elevation of sIL-2R (38). In the present cases, especially in the acute phase of the wife, the findings on chest X-ray, BALF and TBLB showing interstitial inflammation with marked elevation of sIL$2 \mathrm{R}$, were in support of that report. Interestingly, however, the sIL-2R level of the husband was also elevated despite his mild clinical state. Significant elevation of ADA activity and cell free IL-2R (soluble IL-2R) with Mycoplasma pneumoniae pneumonia have been also reported (40). Another experimental study showed an increase in IL-2R-bearing cells in the spleen of BALB/c mice by inoculation of Mycoplasma pneumoniae antigens (41). Taken together, these reports and the present results suggest that one of the determinants of Mycoplasma pneumoniae pneumonia is causally related to $T$ cell activation in vivo, even when the clinical symptoms are not so severe. The more activated the $\mathrm{T}$ cells are, as expressed by the marked elevation of sIL-2R, the more severe is the disease that might develop. This correlation is similar to tuberculous lesions (39). Therefore, the clinical significance of the sIL-2R level as a predictor of severe pneumonia should be emphasized at the early stages of pneumonia, in addition to the diagnostic significance (40).

In some of the previously described pulmonary disorders or autoimmune disorders which show elevated serum sIL-2R, steroid therapy is known to be effective. In fact, in the present wife, the markedly elevated serum sIL-2R was returned to the normal level with marked recovery of pneumonia following pulse therapy. Therefore, in cases of severe Mycoplasma pneumoniae pneumonia, pulse therapy might also be one of the useful therapies, in addition to antibiotic administration $(2,12$, $13,15,22,24,27,29-31,33)$.

In conclusion, we treated a married couple with $\mathrm{Myco}$ plasma pneumoniae pneumonia, one of which developed a severe pneumonia with acute respiratory failure. The difference in their clinical states may be reflected in their serum sIL-2R levels, a marker of T cell activation in vivo. Pulse therapy was very useful in treating the disease, returning the elevated serum sIL-2R level to the normal level. For predicting the severity and determining the treatment of Mycoplasma pneumoniae pneumonia, the serum sIL-2R level appears to be one of the useful clinical markers.

\section{References}

1) Koletsky RJ, Winstein AJ. Fulminant Mycoplasma pneumoniae infection. Am Rev Respir Dis 122: 491, 1980.

2) Wakasa M, Hirose T, Matsuo S, Kubo C, Inoue T, Nagano H. Respiratory failure secondary to Mycoplasma pneumoniae infection. Nippon Kyobu Shikkan Gakkai Zasshi (Japanese Journal of Thoracic Diseases) 24: 430, 1986 (Abstract in English).

3) Takamatsu K, Nakano Y, Komatsu H, et al. A sudden death case of Mycoplasma pneumoniae pneumonia complicated by Guillain-Barré syndrome, arrythmia and abnormal ECG. Naika (Internal Medicine) 57: 369, 1986 (in Japanese).

4) Izumikawa K. Recent evidences concerning about the host factor on the development of Mycoplasma pneumonia. Rinsho to Saikin 11: 456, 1984 (in Japanese).

5) Rubin LA, Nelson DL. The soluble interleukin-2 receptor; biology, function and clinical application. Ann Intern Med 113: 619, 1990.

6) Kaufman JM, Cuvelier CA, Straeten MVD. Mycoplasma pneumonia with fulminant evolution into diffuse interstitial fibrosis. Thorax 35: 140 , 
1980.

7) Brunner H. Mycoplasma pneumoniae infection. Isr J Med Sci 17: 516, 1981.

8) Layh-Schmitt G, Herrmann R. Spiral arrangement of gene products of the $\mathrm{P} 1$ operon in the membrane of Mycoplasma pneumoniae. Infect Immun 62: 974, 1994.

9) Murata A, Kudo S. Drug induced pneumonitis. Nihon Naika Gakkai Zasshi (Journal of the Japanese Society of Internal Medicine) 83: 761, 1994 (in Japanese).

10) Cooper JAD Jr, White DA, Matthay RA. Drug-induced pulmonary disease. Part 2: Noncytotoxic drugs. Am Rev Respir Dis 133: 488, 1986.

11) Maisel JC, Babbitt LH, John TJ. Fatal Mycoplasma pneumoniae infection with isolation of organisms from lung. JAMA 202: 287, 1967.

12) Nagaoka $S$, Katoh $K$, Ishigatsubo $Y$, et al. Severe Mycoplasma pneumonia and acute respiratory failure in a patient with PSS. Kansenshogaku Zasshi (Journal of the Japanese Association for Infectious Diseases) 57: 986, 1984 (Abstract in English).

13) Kuraoka T, Tsubota M, Obi M, et al. A case of severe pneumonia infection complicated with disseminated intravascular coagulation and acute respiratory failure. Nihon Kyobu Rinsho (Japanese Journal of Chest Diseases) 44: 932, 1985 (Abstract in English).

14) Nakazumi Y, Takahashi Y, Fujimura M, et al. A case of Mycoplasma pneumonia who developed acute respiratory failure. Nihon Kyobu Rinsho (Japanese Journal of Chest Diseases) 45: 889, 1986.

15) Terada $Y$, Matsunobe S, Muro K, et al. Effects of hydrocortisone in severe Mycoplasma pneumoniae pneumonia. Nippon Kyobu Shikkan Gakkai Zasshi (Japanese Journal of Thoracic Diseases) 25: 203, 1987 (Abstract in English).

16) Hiraoka N, Murao H, Goto I, et al. A severe case of Mycoplasma pneumonia. Shojinkai Ishi 26: 185, 1987 (Abstract in English).

17) Morita $H$, Mizushige $K$, Hirabayashi $K$, et al. A case of perimyocarditis and pneumonia with Mycoplasma pneumoniae infection. Shinzo (Heart) 19: 1435, 1987 (in Japanese).

18) Yokoyama S, Taniguchi H, Kondo Y, Matsumoto K, Nakashima Y. A case of Mycoplasma pneumonia with acute respiratory failure. Progress in Medicine 8: 1705, 1988 (in Japanese).

19) Hayase M, Ohya N, Yamanouchi K, Noguchi T. Bronchiolar lesions in Mycoplasma pneumonia - A case report. Nihon Kyobu Rinsho (Japanese Journal of Chest Diseases) 47: 514, 1988 (Abstract in English).

20) Miyai M, Toyama Y, Tsubota T, Asano T. A case of severe Mycoplasma Pneumoniae pneumonia associated with massive pleural effusion, respiratory failure, erythema and tympanitis. Kokyu (Respiration Research) 7: 1414, 1988 (Abstract in English).

21) Aoki S, Kihira Y, Hasegawa $\mathrm{H}$, Hirose N, et al. Mycoplasma pneumoniae pneumonia presenting hypoxemia and diffuse interstitial shadow on chest roentgenogram. Nihon Kyobu Rinsho (Japanese Journal of Chest Diseases) 48: 637, 1989 (Abstract in English).

22) Shiraishi T, Saisho M, Kawaguchi S, et al. A case of Mycoplasma pneumoniae pneumonia associated with acute respiratory failure. Rinsho to Kenkyu (Japanese Journal of Clinical and Experimental Medicine) 66: 3839, 1989 (in Japanese).

23) Inoue K, Yamada T, Shinno E. Two cases of Mycoplasma pneumonia with atypical clinical courses. Shonika Rinsho (Japanese Journal of Pediatrics) 43: 519, 1990 (in Japanese).

24) Onbe T, Kubo K, Yoshinouchi T, Ohtsuki Y, Sonobe H. A case of Mycoplasma pneumoniae pneumonia associated with acute respiratory failure - follow up of transbronchial lung biopsy. Kokyu (Respiration
Research) 9: 619, 1990 (in Japanese).

25) Nakazono T, Kakihara H, Kato S, Takada M, Yamamoto M. A case of Mycoplasma pneumoniae which presented chest X-ray findings of bilateral multiple and infiltrative shadows. Nagoya Ichiritsu Byoin Kiyo 13: 23, 1990 (in Japanese).

26) Kazama J, Ei I, Kurashige K, et al. A case of pneumonia caused by Mycoplasma pneumoniae associated with acute respiratory failure. Niigata Shimin Byoin Ishi 11: 157, 1990 (in Japanese).

27) Isobe $\mathrm{T}$, Kuraoka $\mathrm{T}$, Sumiyoshi $\mathrm{H}$, et al. Three cases of acute respiratory failure caused by Mycoplasma pneumoniae pneumonia. Hiroshima Igaku 45: 260, 1992 (in Japanese).

28) Ikutani A, Okabayashi K, Ohtani M, Hashimoto M, Hasegawa K, Yamakido M. A case of mixed infection of Legionnaires' and Mycoplasma pneumonia. ICU \& CCU (Japanese Journal of Intensive Care Medicine) 15: 81, 1991 (Abstract in English).

29) Shirai T, Sato A, Okano A, et al. Fulminant Mycoplasma pneumoniae infection presenting with Stevens-Johnson syndrome \& respiratory failure. Nippon Kyobu Shikkan Gakkai Zasshi (Japanese Journal of Thoracic Diseases) 29: 1298, 1991 (Abstract in English).

30) HashiguchiK, Yagi S, Okimoto N, etal. Acase of Mycoplasmapneumoniae pneumonia complicated with ARDS. Kawasaki Igakkaishi 18: 123, 1992 (Abstract in English).

31) Isobe $T$, Kuraoka $T$, Sumiyoshi $H$, et al. Three cases of acute respiratory failure caused by Mycoplasma pneumoniae pneumonia. Hiroshima Igaku 45: 260, 1992 (in Japanese).

32) Shiraishi T, Takasu O, Sakamoto T, Kaku N, Oizumi K. A case of Mycoplasma pneumonia associated with acute respiratory failure and acute renal failure. Naika (Internal Medicine) 71: 971, 1993 (in Japanese).

33) Okimoto N, Tatara S, Yoshida K, Nakashima M, Sejima R. Mycoplasma pneumonia cured by steroid therapy. Kokyu (Respiration Research) 12: 1302, 1993 (in Japanese).

34) Smith CB, Fridewald WT, Chanock RM. Inactivated Mycoplasma pneumoniae vaccine. Evaluation in volunteers. JAMA 199: 353, 1967.

35) Hayashi S, Ichikawa Y, Fujino K, et al. Analysis of lymphocyte subsets in peripheral blood and bronchoalveolar lavage fluid in patients with pneumonia due to Mycoplasma pneumoniae. Nippon Kyobu Shikkan Gakkai Zasshi (Japanese Journal of Thoracic Diseases) 24: 162, 1986 (Abstract in English).

36) Obara T, Kung PC. Cell free IL-2R test kit for determination of soluble IL-2R receptor (sIL-2R) in the human serum. Rinsho Kensa (Journal of Medical Technology) 35: 539, 1991 (in Japanese).

37) Lai CKW, Chan CHS, Leung JCK, Lai K. Serum concentration of soluble interleukin 2 receptors in asthma. Correlation with disease activity. Chest 103: 782, 1993

38) Abe $Y$, Hirata $M$, Nirana $H$, et al. Study of interstitial pneumonia associated with interferon therapy on $\mathrm{C}$ type chronic hepatitis and serum soluble IL-2 receptor (sIL-2R). Rinsho to Kenkyu (Japanese Journal of Clinical and Experimental Medicine) 71: 791, 1994 (in Japanese).

39) Chan CHS, Lai KN, Leung JCK, Lai CKW. T lymphocyte activation in patients with active tuberculosis. Am Rev Respir Dis 144: 458, 1991.

40) Suga M, Ando M, Nishikawa H, Araki S. Adenosine deaminase activity and free IL-2 receptor elvels in serum from patients with Mycoplasma pneumonia. Jpn J Med 30: 108, 1991.

41) Pietsch K, Jacobs E. Characterization of the cellular response of spleen cells in BALB/c mice inoculated with Mycoplasma pneumoniae or the P1 protein. Med Microbiol Immunol 182: 77, 1993. 